\title{
EL COLEGIO DE TEPOTZOTLÁN Y LA DISCIPLINA DEL CLERO SECULAR EN EL ARZOBISPADO DE MÉXICO, 1777-1821
}

\author{
POR \\ Mónica Hidalgo Pego \\ Iisue-Unam
}

\section{RESUMEN}

En 1777, el arzobispo de México Alonso Núñez de Haro fundó en el pueblo de Tepotzotlán, el colegio seminario para instrucción, retiro voluntario y corrección de clérigos seculares. Esta institución, única en su tipo, se estableció para formar curas perfectos y para corregir a los eclesiásticos que por sus delitos o por falta de instrucción, lo necesitasen. Los mecanismos utilizados para ello serán estudiados en el presente trabajo.

Palabras Clave: Arzobispado de México, siglo xVIII, colegio, instrucción, disciplina.

\section{TEPOTZOTLAN COLLEGE AND DISCIPLINE OF SECULAR CLERGY IN THE ARCHBISHOP OF MEXICO, 1777-1821}

\begin{abstract}
In 1777, the archbishop of Mexico Alonso Núñez de Haro founded in the town of Tepotzotlán, the college seminary for training, voluntary recall and correction of the secular clergy. This institution, unique in its kind, was established to train priests perfect and to correct those ecclesiastics who for their crimes or lack of education, needed it. The mechanisms used for this purpose are examined in this work.
\end{abstract}

KEY WORDS: Archbishop of Mexico, eighteenth century, college, instruction, discipline.
Recibido/Received
$11-08-2011$
Aceptado/Accepted
08-11-2013 
En 1769, mediante cédula real del 21 de agosto, Carlos III prescribió la celebración de concilios provinciales en América y Filipinas para arreglar ciertos «desórdenes» de los eclesiásticos, mejorar la moral del clero, favorecer el cumplimiento de sus deberes espirituales y exterminar las doctrinas relajadas. ${ }^{1}$ Para llevar a buen puerto las tareas encomendadas, el monarca incluyó en la cédula real conocida como Tomo Regio, veinte puntos que debían ser atendidos por los prelados en las reuniones conciliares.

De ellos, es interesante destacar el contenido de los puntos XII, XIII, XIV y XV. En el primero, el rey ordenó reformar la conducta del clero y apartarlo de comercios y granjerías; en el segundo, mandó a recluir a los eclesiásticos trasgresores y a revitalizar «los objetos propios de la vocación clerical»; en el tercero dispuso que cada diócesis aceptara un número determinado de sacerdotes para que sólo se ordenara a los más convenientes, «pues la abundancia excesiva les hace menos apreciables». En el último punto, decretó la erección de seminarios donde residirían por espacio de seis meses, todos los ordenados para acostumbrarse a la vida en comunidad, conocer sus defectos particulares y perfeccionar sus conocimientos de teología, moral, liturgia, ritos y disciplina eclesiástica. $^{2}$

En la Nueva España, el concilio se llevó a cabo en 1771 y se realizó teniendo presentes los puntos dictados por el soberano en la cédula real. Con base en los cuatro aspectos señalados arriba, los cánones del sínodo dictaminaron lo siguiente: los obispos tenían la obligación de examinar las calidades y méritos de los aspirantes a las órdenes sacerdotales, «sin que se admitan a los que fueren menos dignos, ni con pretexto de escasez o necesidad de ministros». Los pretendientes al sacerdocio debían ser de buena vida y costumbres, virtuosos, honestos y recogidos, inclinados al estudio, al servicio de Dios, a los sacramentos y las funciones eclesiásticas. Todos los que desearan ordenarse debían ejercitarse durante seis meses en las casas o seminarios designados para cumplir con esa función. Durante su estadía, los residentes serían instruidos en la sagrada liturgia, materias morales y obligaciones del estado eclesiástico. ${ }^{3}$

Para reformar la conducta pública del clero, el concilio hizo hincapié en la vestimenta de los clérigos y en las actividades que les estaban prohibidas,

\footnotetext{
${ }^{1}$ Cervantes Bello, F. J. y Cano Moreno, S. M. 2005. «El IV Concilio Provincial Mexicano», en M. P. Martínez López-Cano y F. J. Cervantes Bello (coords.), Los concilios provinciales en Nueva España. Reflexiones e influencias: 72. México: Instituto de Investigaciones Históricas/Benemérita Universidad Autónoma de Puebla.

${ }^{2}$ Zahino Peñafort, L. (recop.), 2009. El cardenal Lorenzana y el IV Concilio Provincial Mexicano: 51-52 México: Instituto de Investigaciones Jurídicas.

${ }^{3}$ Ibídem. Libro I, título IV, De la edad y calidades de los que se han de ordenar y del escrutinio que se ha de hacer, 67-72.
}

Hispania Sacra, LXVI

134, julio-diciembre 2014, 601-619, ISSN: 0018-215X, doi: 10.3989/hs.2014.063 
entre ellas destacan, tocar instrumentos en las concurrencias, bailar, asistir a fiestas, ejercer oficios mecánicos, tratar con mujeres, usar armas y embriagarse. Tampoco podrían participar en juegos de apuestas o azar, banca, albures, dados, gallos, pelotas, argollas, etc. ${ }^{4}$ Por último, el texto conciliar señaló que los clérigos delincuentes que reincidieran en sus faltas, serían castigados con severidad, y a los acusados por tercera vez del delito de incontinencia, se les recluiría en los colegios o conventos destinados para ese fin. ${ }^{5}$

Los cánones del sínodo nunca fueron aprobados, sin embargo, su estudio resulta relevante, pues se perfilaron en ellos, de la forma más acabada posible, las características y cualidades del cura ideal. ${ }^{6}$ Ese cura debía ser un hombre de vocación sólida, disciplinado, de moral intachable y de formación sobresaliente. Para alcanzar ese grado de perfección, el concilio estableció las materias que los sacerdotes debían dominar y legisló sobre las instituciones donde afinarían sus conocimientos y donde serían encerrados en caso de comportamiento lascivo.

Los mitrados que llegaron al territorio novohispano en los años posteriores, intentaron que los clérigos de sus obispados reunieran las calidades y particularidades establecidas en el concilio. Los medios utilizados para alcanzar este objetivo fueron distintos en cada diócesis. En Guadalajara, por ejemplo, el obispo Juan Cruz Ruiz de Cabañas se dedicó a eliminar la relajación de costumbres de los clérigos y a formar ministros responsables en el ejercicio de su ministerio. ${ }^{7}$ Incluso 25 años después de que en la arquidiócesis de México, el arzobispo Alonso Núñez de Haro y Peralta fundara su seminario, Cabañas erigió el Colegio Clerical del Divino Salvador. ${ }^{8}$

En las siguientes páginas, no se pretende estudiar la historia del seminario, sino los métodos empleados al interior del mismo para trasformar a los clérigos seculares del arzobispado mexicano en curas ejemplares. El trabajo tiene como sustento las constituciones redactadas por Haro y Peralta en 1775.

${ }^{4}$ Ibídem. Libro III, título VI, De la vida y honestidad de los clérigos, 201-206.

${ }^{5}$ Ibídem. Libro V, título X, Del concubinato y de las penas de los concubinarios y rufianes, 270.

${ }^{6}$ El Tercer Concilio Provincial Mexicano, basando en los cánones del sínodo realizado en la ciudad de Trento, definió algunas de las características y cualidades que debían poseer los clérigos. Los asistentes al cuatro concilio retomaron muchas de ellas y agregaron nuevas.

${ }^{7}$ Gutiérrez Lorenzo, M.P. 2005. «Universitarios alcalaínos en la Nueva España. Destinos profesionales en la Nueva Galicia» en E. González González y M. L. Pérez Puente (coords.), Permanencia y cambio I. Universidades hispánicas, 1551-2001: 401. México: Centro de Estudios sobre la Universidad/Facultad de Derecho.

${ }^{8}$ Sobre este seminario pueden consultarse los siguientes textos, Romero Delgado, J. 1990. «El obispo Ruiz de Cabañas y la erección y fundación del Colegio Clerical Del Divino Salvador: Guadalajara, 1802». Communio 2: 1-10 y del mismo autor, 1991. Aportaciones pedagógicas desde la formación del clero. Los seminarios reformados por Luis de Cabañas, (Guadalajara 1800-1813) Cuestiones pedagógicas 1: Huelva. 


\section{FUNDACIÓN DEL SEMINARIO}

En 1586, la Compañía de Jesús edificó en el pueblo de Tepotzotlán, perteneciente al arzobispado de México, el Colegio de San Francisco Xavier; en él se instituyó el noviciado y la casa de probación de la Orden. ${ }^{9}$ En 1767, al decretarse el extrañamiento de los regulares de Loyola, el establecimiento fue cerrado. Cinco años más tarde, el virrey Antonio María de Bucareli informaba al presidente del Consejo de Castilla, que la Real Junta Superior de Aplicaciones de México, ${ }^{10}$ en su sesión del 28 de noviembre de 1770, había dispuesto que el edificio sirviera como hospicio o residencia de los misioneros que viniesen de los seminarios de Villagarcía y Loyola y como casa de reclusión y ejercicios de órdenes. ${ }^{11}$

Las funciones asignadas a la institución fueron sugeridas o tal vez impuestas por el entonces arzobispo Francisco Antonio de Lorenzana y respondían a lo ordenado por el monarca en las reales cédulas del 14 de agosto de 1768 y del 21 de agosto de 1769. En la primera, el rey dictaminó la fundación de seminarios de misiones donde se formaran los sacerdotes encargados de difundir la fe católica a los infieles. Los seminarios debían contar con casas en América y Filipinas en las que se hospedaría a los seminaristas durante el tiempo de su detención y hasta que fueran destinados a una misión. Ahí recibirían la instrucción necesaria para desempeñar su ministerio, conocer el territorio y enterarse de sus costumbres. ${ }^{12}$ También decretó el establecimiento de casas correccionales para «...reducir a los caminos de la virtud, y de su vocación, a los clérigos relaxados que se hallaban separados de ella...» ${ }^{13}$ Para los ejercicios de órdenes, como ya hemos señalado, el rey prescribió en la cédula de 1769, la erección de seminarios en las casas que habían pertenecido a los jesuitas.

Las cédulas reales hacen referencia a tres tipos diferentes de establecimientos, aunque Lorenzana decidió reunirlos en uno solo. Sin embargo, el prelado no puedo concretar los planes que tenía para el recinto, pues abandonó la Nueva España en 1772 para ocupar la silla episcopal de la arquidiócesis de Toledo;

\footnotetext{
${ }^{9}$ La casa de probación se erigió en 1606. Rodríguez Ogarrio, J. C. 2005. La política educativa de los jesuitas hacia los indígenas entre 1575 y 1594: 49 México: Facultad de Filosofía y Letras.

${ }^{10} \mathrm{La}$ junta de aplicaciones de la capital del virreinato fue fundada por real cédula del 9 de julio de 1769. Su erección respondía a la cédula fechada en 14 de agosto de 1768 , en la cual se ordenaba la fundación de Juntas Superiores, las cuales se encargarían de analizar la situación, el manejo y la aplicación que debía darse al patrimonio de la Compañía de Jesús.

${ }^{11}$ Archivo General de la Nación, México (AGNM en adelante), Real Junta, vol. único, fs. 34-36.

${ }^{12} 1805$. Novísima recopilación de la leyes de España dividida en XII libros en que se reforma la recopilación publicada por el señor Felipe II en el año de 1567 reimpresa últimamente en el de 1775. $Y$ se incorporar las pragmáticas, cédulas, decretos, órdenes y resoluciones reales, y otras providencias no recopiladas y expedidas hasta el de 1804: 96 Madrid.

${ }^{13}$ Archivo General de Indias, (AGI en adelante), L.A. 51, Colección General de Providencias relativas a la expulsión de la Compañía de Jesús, 63.
}

Hispania Sacra, LXVI

134, julio-diciembre 2014, 601-619, ISSN: 0018-215X, doi: 10.3989/hs.2014.063 
tres años después, Alonso Núñez de Haro y Peralta, su sucesor, ${ }^{14}$ retomaría el proyecto.

A fin de concretarlo, el arzobispo envió en diciembre de 1775, una carta al monarca donde le solicitaba permiso para fundar en el edificio de Tepotzotlán que había pertenecido a los jesuitas, un seminario de «...ynstrucción para su clero secular, y de retiro, assí para que los clérigos desengañados acabasen con quietud sus días, como de corrección para recluir en él a los que, o por sus delitos o por falta de instrucción, lo necesitasen». ${ }^{15}$ Haro y Peralta también contemplaba que el colegio sirviera como hospicio de misioneros.

Como se puede apreciar, retomó las tres funciones asignadas al seminario por su antecesor e incluyó la de casa de retiro, atendiendo a lo dispuesto por el monarca en la cédula de 1768. La misiva iba acompañada de las constituciones elaboradas por el prelado para el régimen y gobierno del colegio. ${ }^{16}$

La cédula que autorizó la apertura del seminario fue expedida en Madrid, el 28 de marzo de 1777. En ella, el rey señaló que había aceptado el proyecto por considerarlo del agrado de Dios y de su real servicio, «para el exemplo y

\footnotetext{
${ }^{14}$ Alonso Núñez de Haro y Peralta nació en Villagarcía del Llano, Cuenca, en 1729. Estudió filosofía y teología con los dominicos de San Pedro Mártir, posteriormente se traslado al Colegio Mayor de San Clemente de los Españoles, donde incorporó su grado de doctor en teología. Fue canónigo lectoral de Cuenca, Segovia y Toledo. En la última ciudad fue visitador general y administrador perpetuo de la Casa de niños expósitos. En 1772 fue nombrado arzobispo de México; durante su gestión realizó numerosas visitas pastorales, inició la reforma de la orden de la Caridad y de San Hipólito, efectuó la visita del Colegio Mayor de Santa María de Todos Santos, presidió los capítulos provinciales de los agustinos calzados y el capítulo general de los betlemitas. Fundó dos colegios de religiosas descalzas, el colegio de instrucción de niñas de Belén y la casa de expósitos. Redactó las constituciones del Hospital de San Andrés. Del 18 de mayo al 16 de enero de 1787 fue virrey interino de la Nueva España. En 1792 se le condecoró con la Cruz de Carlos III. Murió en la ciudad de México el 26 de mayo de 1800.

${ }^{15}$ AGI, México, 2530, exp. 3, Constituciones que se han de observar en el Real Colegio Seminario de Instrucción, retiro voluntario y corrección de Tepotzotlán, f. $3 \mathrm{r}$.

${ }^{16}$ El documento legislativo elaborado por Núñez de Haro consta de una introducción y cincuenta constituciones que pueden subdividirse en cinco grupos: espiritual, temporal, económico, habitantes y oficios. El espiritual comprende las normas relacionadas con la oración, la convivencia, las mortificaciones, las misas, las virtudes, el silencio, la clausura. El temporal incluye lo relativo al calendario y jornada escolar, vacaciones y recreaciones, distribución del tiempo, dieta alimenticia, conducta en el refectorio, habitaciones y aulas, horas de descanso, estudio y recreación. El económico indica los salarios de las autoridades, catedráticos y oficiales, la forma de organizar la contabilidad de los ingresos y egresos, la manera de administrar las haciendas y la distribución de la despensa. En lo referente a los habitantes se habla de los diferentes tipos de clérigos que residirían en el colegio y del modo en que ingresarían. Con relación a los oficios se establecen las cualidades morales y académicas que debían poseer las autoridades y lectores. González M., J. R. y Ordoñez A., M. M. (comps.), 1993. Colegio seminario de Tepotzotlán para instrucción, retiro voluntario y corrección de clérigos seculares. Constituciones formadas por el arzobispo de México (El ilustrísimo señor doctor don Alonso Núñez de Haro y Peralta) para su gobierno, y cédula del 28 de marzo de 1777 aprobándolas con las limitaciones y declaraciones que expresa: 11 México: Instituto de Antropología e Historia.
} 
enseñanza que darán a todo el clero secular y regular, unos ecclesiásticos que desengañados se retiren voluntariamente a emplearse en un fin tan santo». ${ }^{17}$

En el mismo documento, Carlos III aprobó las constituciones, pero con algunas modificaciones alusivas a sus derechos de patronato, así por ejemplo, indicaba que el virrey, en su calidad de vicepatrono de la institución, debía elegir a los catedráticos, aprobar las cuentas anuales y dar su consentimiento para modificar los estatutos. ${ }^{18}$

Señalaba además que la junta de aplicaciones, atendiendo a las súplicas del metropolitano, le había entregado el edificio interinamente desde $1775 .{ }^{19}$ Durante el interinato, Haro y Peralta nombró a las autoridades y catedráticos ${ }^{20}$ y realizó las gestiones financieras necesarias para ponerlo en funcionamiento, poco tiempo después de recibir la aprobación real.

La cédula real llegó a México a finales de 1777 y para oficializar la fundación del seminario, el arzobispo mandó a publicar el 18 de diciembre de mismo año, un edicto dirigido a los clérigos y fieles del arzobispado. ${ }^{21}$

\section{HABITANTES DEL SEMINARIO}

En la constitución titulada, De los habitantes del seminario y de las cosas que pertenecen a la moderación, instrucción y perfección de ellos. De los habitantes y su ingreso, ${ }^{22}$ se establece que el seminario atendería a los siguientes clérigos: ordenados, retirados voluntarios y reclusos por delito o falta de instrucción.

La licencia para el ingreso de todos los residentes debía ser otorgada por el arzobispo o por los provisores y vicarios generales. En el decreto de admisión se

\footnotetext{
${ }^{17}$ AGI, México, 2530, exp. 3, Constituciones que se han de observar...f. $6 \mathrm{v}$.

${ }^{18}$ Ibídem. fs. 6v-7r.

${ }^{19}$ Ibídem. f. 3v.

${ }^{20}$ Pensamos que así fue, pues la carta pastoral del 15 de febrero de 1776, esta dirigida al rector, vicerrector, catedráticos y directores de Tepotzotlán. En la pastoral el prelado habla a sus receptores de la importancia de contar con un colegio donde se instruya a los individuos que serán promovidos al sacerdocio y donde se observe si poseen las virtudes y cualidades necesarias para ejercer adecuadamente su ministerio. 1807. Sermones escogidos, pláticas espirituales privadas y dos pastorales anteriormente impresas en México del excelentísimo señor D. Alonso Núñez de Haro y Peralta, virrey interino, gobernador y capitán general que fue de Nueva España; caballero prelado, gran cruz de la orden española de Carlos III, del Consejo de S.M., arzobispo de México, etc. Con el retrato del autor y un resumen histórico de su vida. Tomo III, cartas pastorales I y II: 12. Madrid: Imprenta de la hija de Ibarra.

${ }^{21}$ González M., J. R. y Ordoñez A., M. M. 1993: 10.

${ }^{22}$ AGI, México, 2530, exp. 3, Constituciones que se han de observar... constituciones vigésima quinta a vigésima octava, fs. 20r-26v.
}

Hispania Sacra, LXVI

134, julio-diciembre 2014, 601-619, ISSN: 0018-215X, doi: 10.3989/hs.2014.063 
estipularía la causa por la cual se les había remitido, lo que el rector debía hacer con cada uno y el monto de su pensión.

Los ordenados residirían en Tepotzotlán seis meses continuos o intercalados. ${ }^{23}$ Durante su estadía, los eclesiásticos aprenderían a vivir en comunidad, practicarían las virtudes y serían instruidos en ritos y ceremonias:

Para rezar bien el oficio divino y celebrar con perfección el santo sacrificio de la misa. En la oratoria, para que con fruto y acierto prediquen la divina palabra; en el modo de administrar recta y debidamente los santos sacramentos y en la doctrina sana para que impressionados de ella puedan darla a los demás y ser útiles así y al público. ${ }^{24}$

A lo largo de los seis meses, el catedrático de historia eclesiástica observaría de manera constante, las actitudes, forma de vida, costumbres, aprovechamiento e inclinaciones de cada ordenado para que:

Instruido el rector, nos informe antes de ordenarles, de los que juzga a propósito para ministros de el Señor, y de los que no lo sean, para ordenar a sólo aquellos de cuya providad e idoneidad esperamos que podrán desempeñar enteramente las funciones del alto ministerio a que anhelan, y les prevenimos que sólo conferiremos las sagradas órdenes a aquellos que con su arreglo de vida y aprovechamiento se hagan acreedores a ello. ${ }^{25}$

Con esta medida, se cumpliría con lo dispuesto en el punto XIV del Tomo Regio y en los decretos del IV Concilio Provincial Mexicano.

El número de ordenados en el periodo estudiado no es fácil de precisar, sin embargo, se cuenta con algunos datos que pueden darnos una idea aunque sea parcial. En 1796, como se puede inferir de la cuenta y relación jurada del mayordomo, había 44 individuos. ${ }^{26}$ En 1806 residían 41, y en 1816, únicamente cuatro, según datos proporcionados por el encargado de realizar la visita al colegio en ese año. Resulta complicado conocer las causas del declive de la matrícula, no obstante, el vicerrector señala que en 1809, ya no se exigía a los ordenados morar en Tepotzotlán y por esa razón asistían pocos y por el tiempo que les apetecía. ${ }^{27}$ Por su parte, Luisa Zahino nos dice que tras la muerte del fundador en 1800, el establecimiento entró en una etapa de decadencia financiera, y que para 1816 , se le debían 9,600 pesos. $^{28}$

\footnotetext{
${ }^{23}$ Los ordenados que fueran colegiales actuales de San Ildefonso, Santa María de Todos Santos y el Seminario Conciliar de la Santísima Trinidad estaban exentos de esta obligación.

${ }^{24}$ AGI, México, 2530, exp. 3, Constituciones que se han de observar... constitución vigésima sexta, De los ordenados, f. 23v.

${ }^{25}$ Ibídem. Constitución trigésimo sexta, Del oficio del cathedrático de Historia y Disciplina Ecclesiástica y segundo director de exercicios», f. 42r.

${ }^{26}$ AGNM, Indiferente virreinal, caja 3998, exp. 013, f. 3r.

${ }^{27}$ Ibídem., f. 39v.

${ }^{28}$ Zahino Peñafort, L. 1996. Iglesia y sociedad en México, 1765-1800. Tradición, reforma y reacciones: 88 y 187 México: Instituto de Investigaciones Jurídicas. En 1812, temporalidades dejó de
} 
Los retirados voluntarios eran clérigos y curas del arzobispado que por inclinación o vocación decidían retirarse para tener una vida tranquila, una existencia perfecta o una buena muerte. Permanecían en la institución el tiempo que ellos consideraban pertinente. Los jubilados tenían la obligación de asistir a las oraciones, lecciones, exámenes, refectorio y conferencias de moral y ritos. Para servir de ejemplo a los demás habitantes del colegio se les aconsejaba ayudar en las labores de la casa y en la administración del curato. ${ }^{29} \mathrm{Si}$ alguno no podía pagar sus alimentos o el costo de sus enfermedades, el seminario lo sufragaría, siempre y cuando hubiera fondos suficientes.

Hasta el momento la documentación no permite saber si el colegio albergó a clérigos retirados, sin embargo, en las cuentas del seminario existe una partida denominada «otros huéspedes», aunque puede tratarse de los reclusos o de los acompañantes de algunos eclesiásticos. ${ }^{30}$

Los arrestados por falta de instrucción eran enviados al colegio cuando quedaba demostrado, con la ayuda de exámenes u otros mecanismos, que carecían de los conocimientos esenciales para el desempeño de su ministerio. Los recluidos por delito eran remitidos para infundirles la piedad y doctrina de que se hallaban desprovistos y para enmendar su vida relajada. Además de corregir su conducta, las autoridades eclesiásticas asilaban a los clérigos infractores por tres razones principales: evitar que sus crímenes se hicieran públicos, impedir que fueran sancionados por jueces civiles y salvarlos de ir a la cárcel, pues en ella, indicaba el redactor de las constituciones, «...en lugar demmendarse y reformarse, salen...menos corregidos, y tal vez despechados y muy expuestos a reincidir en los mismos delitos...». ${ }^{31}$

Los motivos de reclusión no debían ser conocidos por los demás habitantes del colegio. Para lograr la total discreción, la Secretaría de Cámara daba orden reservada de presentación; dicho mandato sería emitido una vez que el prelado o los provisores y vicarios generales notificaran y aprobaran su encarcelamiento. Al ser liberados, el rector debía borrar del libro de residentes del seminario los datos del clérigo y la falta cometida. Su liberación debía ir acompañada de un decreto de remisión, mientras se les otorgaba, los presos por delito vivirían en rigurosa clausura y sí salían de la casa para dar un paseo irían acompañados del lector de moral.

En nuestra búsqueda hemos encontrado nueve casos de clérigos enviados al seminario por delinquir. Tres fueron remitidos por incontinentes, otros tres

\footnotetext{
pagar los réditos correspondientes al misionero, por esta razón el empleo se suprimió en 1815. En 1816, se ordena la suspensión de la plaza de vicerrector por no existir dinero para sus honorarios. AGNM, Regio Patronato Indiano, Bienes Nacionales, vol. 850, exp. 16, fs. 30r y 49r.

${ }^{29} \mathrm{El}$ curato de Tepotzotlán fue agregado al colegio para que estuviera mejor administrado.

${ }^{30}$ AGNM, Indiferente virreinal, caja 3998, exp. 013, f. 4v.

${ }^{31}$ Ibídem. f. 25v.
}

Hispania Sacra, LXVI

134, julio-diciembre 2014, 601-619, ISSN: 0018-215X, doi: 10.3989/hs.2014.063 
fueron consignados por embriaguez, infidencia y solicitación y de los restantes se desconoce la fechoría cometida. Las penas impuestas estaban encaminadas a reformar y no a castigar. Los castigos y los años de reclusión dependían de la gravedad del delito; veamos dos ejemplos; en 1790, el bachiller Miguel de Rivera fue remitido al establecimiento al ser encontrado nuevamente en estado de ebriedad. El rector de Tepotzotlán le impuso una condena de tres años, durante los cuales se le sometió a clausura rigurosa. En 1784, Ignacio Basurto fue remitido por haber confesado a una india, sin ser confesor; se le recluyó un año y su penitencia consistió en ayunar durante varios años, el día que perpetró el ilícito. ${ }^{32}$

Los misioneros procedentes de los colegios de Loyola y Villagarcía no deben ser contemplados dentro de los grupos de beneficiarios del seminario, debido a que venían al seminario en calidad de catedráticos de lengua mexicana y otomí. También debían enseñar la doctrina cristiana, predicar, dar sermones y pláticas doctrinales a los indios del pueblo de Tepotzotlán y de otras poblaciones de la comarca, así como exhortarlos a hacer una buena confesión y a comulgar. ${ }^{33}$ Desconozco si vinieron misioneros de esos colegios al territorio novohispano.

\section{LOS FINES Y LOS MEDIOS}

En la constitución intitulada, De las cosas que pertenecen al gobierno general del seminario. Segunda del gobierno espiritual», Haro y Peralta expresaba que el seminario tenía como fin principal,

la mayor gloria de Dios, y no sólo procurar el proprio aprovechamiento espiritual de los que en él habitaren, sino también la instrucción, moderación y perfección de todo el estado eclesiástico y la salud espiritual de todos los próximos, y siendo cierto que, el propio aprovechamiento se adquiere por la oración, mortificación, desprecio del mundo, imitación de Christo y práctica de las demás virtudes; la instrucción, moderación y perfeción de el estado eclesiástico se puede lograr instituiendo y ordenando sacerdotes a sólo aquellos que adornados de la virtud, doctrina y ciencias necesarias, desean dedicarse a los ministerios apostólicos y cuidando que hagan exercicios espirituales, no sólo los ordenados, sino también los párrocos y todos los eclesiásticos... ${ }^{34}$

${ }^{32}$ AGNM, indiferente virreinal, caja 2223, exp. 001, 20 fojas e inquisición, vol. 1193, exp. 25, fs. 275-284.

${ }^{33}$ AGI, México, 2530, exp. 3, Constituciones que se han de observar... constitución cuadragésima sexta, De las misiones, fs. $47 \mathrm{v}-50 \mathrm{r}$.

${ }^{34}$ Ibídem. fs. 9v-10r. Sobre las ideas pedagógicas de Núñez de Haro vertidas en las constituciones del colegio existe el siguiente texto: Romero Delgado, J. 1986. Ideas pedagógicas de Nuñez de Haro, a través de las constituciones que redactó para el seminario de Tepotzotlán: Nueva España 1777, Huelva: Copistería Escuela Universitaria. Desafortunadamente no he podido localizar el texto en las bibliotecas mexicanas y en las españolas existe, pero no está digitalizado. Por su parte, Alejos Grau C. J. en su artículo 2008. «Vida cotidiana del clero novohispano en el apogeo de la ilustración colonial» Uku 
Para que los clérigos se beneficiaran espiritualmente, el arzobispo dispuso que todos los días realizaran las siguientes actividades: oración mental y vocal, examen de conciencia, lección espiritual y mortificación. ${ }^{35}$ Mientras rezaban, los eclesiásticos debían reflexionar sobre el verdadero sentido de las oraciones y de los misterios del Rosario. Al examinar sus conciencias debían pensar si lo hecho en ese día provenía de la caridad y si su finalidad había sido glorificar al Señor. Del mismo modo, tenían que cavilar sobre sus defectos y descubrir el modo de erradicarlos. Mediante la lección espiritual regocijaban el alma, ${ }^{36}$ y con las mortificaciones de la mente y el cuerpo imitaban a Cristo. ${ }^{37}$

También se prescribió la práctica constante de las cinco virtudes celestiales: caridad, humildad, obediencia, castidad y paciencia. Con la caridad los clérigos lograrían amar a Dios sobre todas las cosas y a los prójimos como a ellos mismos; esta virtud debía unirse especialmente con la paciencia, pues teniendo las dos, todo se podía vencer. La humildad los haría sencillos, sensatos, dóciles y gentiles; la obediencia les enseñaría a acatar la voluntad de sus superiores, especialmente del papa, el rey, los prelados, el rector y los decretos conciliares. Para imitar la pureza de Jesús, los ministros desempeñarían el misterio del confesionario con prudencia; evitarían conversar con mujeres, separarían las emociones y potencias de los objetos peligrosos:

Huiendo enteramente de el ocio, guardando templanza en el comer y beber, absteniéndose de leer libros prophanos, y opuestos a la santidad y la inocencia como son los que tratan de comedias, novelas y otros semejantes, y finalmente pidiendo a Dios con humildad, les conceda la celestial virtud de la castidad.» ${ }^{38}$

Alonso consideraba que mediante el ejercicio de las cinco virtudes, los curas podrían «ascender al monte de la perfección, lograr la vida eterna y conducir [a] otros a ella con su edificación y doctrina». ${ }^{39}$

Pacha. Revista de Investigaciones Históricas 12: 71-86, da cuenta de la vida cotidiana del seminario, de las personas que desempeñaban los cargos de autoridad y las cátedras dentro del establecimiento y del régimen seguido por los sacerdotes reclusos.

${ }^{35}$ Lo relativo a las actividades indicadas se encuentra legislado en las constituciones tercera a sexta y octava, fs. $10 \mathrm{r}$ a $12 \mathrm{v}$.

${ }^{36}$ Todos los días a las dos de la tarde, en la capilla del colegio, uno de sus residentes debía leer durante media hora pasajes de las obras de San Francisco de Sales, Santa Teresa, fray Luis de Granada u otro autor semejante. Se hacia lo propio en la comida y cena, pero se elegía un capítulo de la Biblia y un personaje, suceso o misterio del martirologio.

${ }^{37}$ Las mortificaciones consistían en comer de vigilia, ayunar, rezar de rodillas y frenar las pasiones, sentidos y debilidades.

${ }^{38}$ AGI, México, 2530, exp. 3, Constituciones que se han de observar... constitución décima cuarta, De la paciencia, fs. $15 \mathrm{v}$.

${ }^{39}$ Ibídem. Constitución novena, De las virtudes que deben adquirir, f. 13r.

Hispania Sacra, LXVI

134, julio-diciembre 2014, 601-619, ISSN: 0018-215X, doi: 10.3989/hs.2014.063 
Finalmente, el arzobispo ordenó a los sacerdotes oficiar misa diariamente, cuidando de decirla con la debida preparación, reverencia, devoción y acción de gracias. Los pretendientes a las órdenes sacerdotales y los demás clérigos debían confesarse y comulgar una vez a la semana. ${ }^{40}$

Para que los ordenados y reclusos perfeccionaran los conocimientos adquiridos en otros centros de enseñanza, dispuso la apertura de cuatro cátedras: teología moral, historia y disciplina eclesiástica, lengua mexicana e idioma otomí ${ }^{41}$ También se darían conferencias o academias de moral, historia eclesiástica y liturgia. ${ }^{42}$

La cátedra de teología moral se enseñaría siguiendo la Suma moral para examen de curas y confessores... de Vicente Ferrer. ${ }^{43}$ En la misma clase se explicaría durante la primera media hora un párrafo del Catecismo del Concilio. Los jueves la lección se dedicaría al estudio de la Rhetoricae ecclesiasticae ${ }^{44}$ de Luis de Granada para que los sacerdotes aprendieran a exponer apropiadamente la doctrina ${ }^{45}$ Los sábados el lector designaría un cursante para que defendiera la condenación de una de las proposiciones censuradas u otro punto controvertido de moral. Finalmente, en el refectorio, uno de sus discípulos realizaría una plática o sermón para enseñar a los demás a detestar los vicios o para incitarlos a practicar alguna virtud. La homilía tendría como finalidad acostumbrar a los cursantes a predicar con inteligencia la divina palabra.

Antes de comenzar el estudio de la historia y disciplina eclesiástica, el catedrático cuidaría que sus alumnos aprendieran las reglas de la cronología

\footnotetext{
${ }^{40}$ Ibídem. Constitución séptima, De la misa y comuniones, f. 11v.

${ }^{41}$ En la constitución trigésima de los estudios, Núñez de Haro pone mucho cuidado en advertir que según lo mandado por su majestad, quedaba totalmente prohibido enseñar por autores que no promovieran la doctrina sana, refiriéndose con ello al probabilismo, es decir, a la doctrina moral que permite en casos dudosos, no dogmáticos o sacramentales seguir la opinión más favorable a la libertad que a la ley. El arzobispo de México Antonio de Lorenzana en su pastoral del 12 de octubre de 1767, que trata sobre la doctrina que se ha de enseñar y practicar, prohíbe enseñar esta doctrina moral, pues considera que el probabilismo había causado la relajación del clero, y especialmente de las órdenes religiosas. Sierra Nava-Lasa, L. 1975. El cardenal Lorenzana y la ilustración: 121 Madrid: Fundación Universitaria Española.

${ }^{42} \mathrm{La}$ constitución que reglamenta los estudios es la trigésima, fs. $27 \mathrm{v}$ a $30 \mathrm{r}$.

43 ...en que a la luz del sol de las escuelas Santo Thomas se desvanecen los perniciosos extremos de laxidad y rigor y fe manifiesta el apreciable medio y camino real de la verdad. Publicada por primera vez en Valencia en 1736. La Suma de Ferrer se inserta en el grupo de obras de confesión que proporcionan a los estudiosos de la teología moral y a los confesores, desde una perspectiva casi técnica, una visión canonizada y fija de la moral católica.

${ }^{44}$ Publicada en Venecia en 1578.

${ }^{45}$ En esta obra, Granada pretende adiestrar a los predicadores en el arte persuasivo y plantea una nueva preceptiva que sirva para la oratoria cristiana en el fondo y en la forma. Sus indicaciones se encaminan hacia el arte de predicar dentro de los modelos de la retórica. Alonso, J. C. 2000. «Adaptaciones a la retórica eclesiástica: fray Luis de Granada y fray Diego Valadés», en J. Arribas (coord.), Temas de retórica hispana renacentista: 100. México: Instituto de Investigaciones Filológicas.
} 
siguiendo el libro, Clave historial con que se abre la puerta a la historia eclesiástica y política... ${ }^{46}$ del agustino Enrique Flórez de Setién y Huidobro. ${ }^{47}$ Una vez instruidos en las reglas de la cronología, el maestro iniciaría las lecciones de historia de la Iglesia utilizando el texto, Historia ecclesiastica variis colloquis del dominico francés Ignacio Jacinto Amat de Graveson..$^{48}$ Los jueves, una hora antes de la clase, los clérigos tendrían lecciones de ritos y ceremonias, usando como texto, Las rúbricas del misal romano reformado, escrito por el obispo Gregorio Galindo. ${ }^{49}$ Los sábados, un estudiante defendería un punto controvertido de historia eclesiástica y los demás le argumentarían. ${ }^{50}$

Los papeles de la visita efectuada al colegio en 1816 nos permiten afirmar que la materia de historia y disciplina eclesiástica se convirtió

desde los principios en cátedra de moral por ser raros los que vienen con principios necesarios para emprender dicho estudio y corto el tiempo de su residencia en el colegio. Y assi en ambas cátedras se ha explicado moral por los padres Ferrer y Grosin según a parecido a los catedráticos y nunca por otros autores.$^{51}$

Las cátedras de lengua mexicana y otomí serían cursadas por los clérigos del seminario que estuvieran ordenados a título de idioma. Los cursantes aprenderían

${ }^{46}$...chronología de los papas, y emperadores, reyes de España, Italia, y Francia, con los orígenes de todas las monarquías: concilios, herejes, santos, escritores, y sucesos memorables de cada siglo, publicado en Madrid en 1743. Entre 1743 y 1817 se hicieron 16 reimpresiones de la obra.

${ }^{47} \mathrm{La}$ obra pretende ser una introducción a la historia universal del siglo I al siglo XVIII. El autor estableció en ella una serie de reglas o criterios para el estudio de las fuentes. Esta concebida para ayudar a los más jóvenes y por esa razón Enrique Flórez se la dedica a ellos. Ripoll López, G. 1989. «Historiografía y numismática visigodas entre los siglos XVI y XVIII: Ambrosio Morales y Enrique Florez». Archéologie aujourd 'hui 2: 64.

${ }^{48}$ Este autor fue de los preferidos del reformismo ilustrado, pues intentaba someter las escrituras y el suceder de la Iglesia al «análisis crítico de la historia mediante la división del tiempo en centurias, lo que permitía ahondar como más facilidad didáctica en el mensaje revelado, en el papel de los concilios, en los Padres de la Iglesia, en personajes relevantes, ideas, etc. La obra fue publicada en nueve volúmenes, los cuales aparecieron entre 1717 y 1721 . Vergara Ciordia, J. 2005. «El seminario conciliar en la América hispana (1563-1800)», en J. I. Saranyana (dir.) y C. J. Alejos Grau (coord.), Teología en la América Latina, Volumen II/1. Escolástica barroca, ilustración y preparación de la Independencia (1665-1810): 179. Madrid: Iberoamericana/Vervuert. De Vergara también puede 2004, Historia y pedagogía del seminario conciliar en Hispanoamérica, 1563-1800: Madrid, Dykinson.

${ }^{49}$ Editado por primera vez en Zaragoza en 1739. También fue publicado en Madrid, Valencia, Gerona, Pamplona, etc. En Nueva España fue impreso cuatro veces entre 1760 y 1778.

${ }^{50}$ Los maestros de historia eclesiástica debían estudiar la materia siguiendo a «Natal Alexandro, Tieuri, Thomasino, Bona, Cabalieri o Merati con Gavanto, para que instruidos en dichos autores puedan resolver con acierto las dudas que les propusiesen sus discípulos y animarse estos a emprender estudios más extensos y perfeccionarse en lo que un eclesiástico bien instruido debe saber», AGI, México, 2530, exp. 3, Constituciones que se han de observar... constitución trigésima, De los estudios, f. 29v.

${ }^{51}$ AGNM, Regio Patronato Indiano, Bienes Nacionales, vol. 850, exp. 18, f. 38r. Francisco Santos y Grosin reformó, corrigió e ilustró con varias constituciones de Benedicto XIV la obra, Prontuario de teología moral, escrita originalmente por el dominico Francisco Lárraga en 1709.

Hispania Sacra, LXVI

134, julio-diciembre 2014, 601-619, ISSN: 0018-215X, doi: 10.3989/hs.2014.063 
las lenguas lo más puramente posible, pues de ello dependía la correcta predica y confesión de los naturales..$^{52}$ Para 1816 , las dos asignaturas quedaron vacantes, debido a que, desde el 1 de enero de 1813, la caja de Consolidación de Vales Reales no entregó al colegio los réditos correspondientes al salario de los lectores. ${ }^{53}$

Para que los habitantes de la institución aprendieran a moderarse, el fundador estableció un conjunto de reglas disciplinares que debían ser observadas por todos tanto al interior del establecimiento como fuera de él, y servirían para regular la conducta individual y colectiva. ${ }^{54}$

En los actos de comunidad, horas de estudio y aulas, los residentes estaban obligados a guardar silencio. Los ordenados y voluntarios que quisieran salir del colegio debían tramitar ante el rector la licencia correspondiente. No se les permitía acercarse a la puerta interior para hablar con personas ajenas al seminario, excepto si la necesidad, caridad, y urbanidad lo demandaban; si se trataba de mujeres que no fueran parientas, les estaba proscrito hablar con ellas a solas. El individuo que dejara entrar a una mujer al establecimiento sería excomulgado.$^{55}$

La simplicidad en las habitaciones de los sacerdotes estimulaba a los seglares, por ello debían abstenerse de adornarlas con cosas costosas y exquisitas, y contentarse con tener una mesa, algunas sillas, estante para libros, cofres para ropa, trastos y pinturas o imágenes de santos, Jesucristo o la Virgen.

En el refectorio, los reclusos tenían una mesa aparte, y los ordenados y voluntarios se sentaban juntos, pero respetando siempre la antigüedad de su grado sacerdotal. Debían comer los alimentos comunes dados por el seminario y utilizar los mismos enseres para que hubiera perfecta igualdad. ${ }^{56}$ Los presos recibían el desayuno que consistía únicamente en chocolate, en el chocolatero destinado para ellos, los voluntarios en el de los empleados, y los ordenados en

${ }^{52}$ AGI, México, 2530, exp. 3, Constituciones que se han de observar... constituciones trigésima octava y trigésima novena, que hablan de los catedráticos de mexicano y otomí, los cuales también eran misioneros, fs. $43 \mathrm{r}$ a $44 \mathrm{r}$.

${ }^{53}$ AGNM, Regio Patronato Indiano, Bienes Nacionales, vol. 850, exp. 18, f. 31.

${ }^{54}$ Las constituciones que legislan sobre la conducta son las siguientes: décima quinta, Del silencio, f. 16, décima séptima, De la clausura, f. 16v-17r, décima octava, Del gobierno temporal. De la distribución del tiempo, fs. 17r a 20r. vigésima, De las recreaciones y vacaciones, fs. 20r-21r. y vigésima novena, Del vestido, fs. $26 \mathrm{v}$ a $27 \mathrm{v}$.

${ }^{55}$ Para que los habitantes del seminario estuvieran conscientes de que las mujeres no podían entrar, debía colocarse por la parte de afuera de la puerta interior, una tablilla donde constara esa prohibición.

${ }^{56}$ En la comida se les daba carne, caldo o sopa, puchero de carnero o ave, dulce y fruta. En la cena ensalada, asado, tomate frijoles y dulce. En la comida del viernes, sopa, huevos o pescado, legumbres, frijoles, dulce o fruta y pan; en la cena se eliminaba la sopa y las legumbres. Los platos debían ser de peltre, los cubiertos de metal; los vasos, tazas y pocillos debían ser decentes y baratos. 
el tercer chocolatero existente en el seminario. No se les permitía guisar fuera de la casa, ni repartir en el refectorio la comida que les regalaban.

Se prohibía bajo la pena de excomunión mayor, jugar dentro y fuera del colegio naipes, dados, banca, gallos o cualquier otro juego prohibido por la Ley de Bandos. Se imponía la misma condena a los que introdujeran bebidas alcohólicas y a los que bebieran fuera de la institución. Tampoco debían asistir a comedias y bailes.

Al interior del colegio, todos los moradores debían vestir traje talar de lana negra, y para concurrir a la oración y a los demás actos de comunidad, agregarían cuello y sotana. Cuando salieran a la calle llevarían bonete y vestido talar negro decente, «manifestando en todas partes la gravedad, moderación y modestia, de manera que en la honestidad de sus vestidos den testimonio a todos de la pureza de sus almas». ${ }^{57}$

Para lograr la perfección del estado eclesiástico, Núñez de Haro instituyó en Tepotzotlán los ejercicios espirituales a los que asistirían, ${ }^{58}$ una vez al año por espacio de diez días, todos los clérigos residentes del seminario y los candidatos al sacerdocio, curas y eclesiásticos que a él se remitiesen. También podrían acudir seglares, siempre y cuando el arzobispo, los provisores o los vicarios generales otorgaran la licencia correspondiente. ${ }^{59}$

Durante ese tiempo, los ejercitantes se dedicarían a examinar su vocación, realizando a lo largo de la mañana una hora de lección espiritual, ${ }^{60}$ otra de examen de conciencia, media hora de oración y otra media para rezar el Rosario entero y sus devociones, y los obligados al oficio divino, las horas canónicas. Si sobraba tiempo lo dedicarían a ratificar los propósitos que hubieren hecho en la oración. Recibirían una plática espiritual sobre los cargos y obligaciones de su estado y sobre diversos asuntos relacionados con su reformación, dirección de almas e imitación de Cristo.

Poco después se reunirían en el refectorio para comer en comunidad y escuchar la lección espiritual. Por la tarde repetirían las actividades matutinas,

\footnotetext{
${ }^{57}$ AGI, México, 2530, exp. 3, Constituciones que se han de observar... constitución décima octava, Del gobierno temporal de la distribución del tiempo en todo el año, fs. $17 \mathrm{r}$ a $19 \mathrm{v}$.

${ }^{58}$ En la carta pastoral del 15 de febrero de 1776, Núñez de Haro mostró su preocupación por la poca inclinación religiosa de los aspirantes al sacerdocio y afirmó que muchos sacerdotes habían perdido su vocación.

${ }^{59}$ AGI, México, 2530, exp. 3, Constituciones que se han de observar... constitución trigésima primera, De los ejercicios espirituales, fs. 30v a 33v.

${ }^{60}$ En las lecciones espirituales de los sacerdotes y clérigos podía leerse a los siguientes autores y textos: Luis de Molina, Manual de sacerdotes de Antonio Arbiol, la Trompeta de Ezequiel, las cartas pastorales siete y ocho de Juan de Palafox. Para los seglares se sugería a Luis de Granada u otros libros semejantes.
}

Hispania Sacra, LXVI

134, julio-diciembre 2014, 601-619, ISSN: 0018-215X, doi: 10.3989/hs.2014.063 
visitarían los altares del coro y la huerta para tener un momento de esparcimiento. Después del paseo, acudirían a la plática espiritual, tendrían oración y examinarían sus conciencias. Con esta actividad, los ejercitantes se preparaban para la confesión general en la que debían demostrar su arrepentimiento y un deseo ferviente de conversión. Al finalizar el día cenarían y se recogerían en sus aposentos.

Haro y Peralta consideraba que al concluir los diez días de ejercicios, los ejercitantes sabrían si en realidad querían recibir las órdenes sacerdotales. También esperaba que los sacerdotes alejados del buen camino renovaran su vocación y cumplieran con exactitud su ministerio.

El caso de Julián Valero, un ejercitante, puede ayudarnos a mostrar la utilidad de los ejercicios espirituales; pues después de concluirlos se acercó al catedrático José Hermenegildo Ruiz Palomero, para decirle que con dictamen de su confesor

...había determinado no ordenarse por parecerle que no era para el estado eclesiástico, pero que si se lo decía a su padre era este capaz de perderlo: que para no ordenarse y librarse de que su padre lo maltratara le diría que yo le había dicho que tenía impedimento que le había puesto, a lo que no accedí por ser mentira y le dije que le avisara a su padre que decía que no podía ordenarse que si se veía conmigo para que le declarase el motivo no lo haría, sino que daría a Vuestra Señoría parte de la violencia que me dice le infiere su padre. Vino por su hijo más no contento conmigo el joven me dixo: que su padre se había conformado con lo que le dixo y determinaba llevárselo en derechura para su tierra hasta donde permanecería hasta otros órdenes. Anoche me dijeron que habían ido padre e hijo para esa ciudad y recelando que este joven vaya a ordenarse por amenazas que el padre le haya hecho, se lo participo a Vuestra Señoría para que haga y determine lo que en el caso sea más conveniente. ${ }^{61}$

Desconocemos si Francisco Javier de Lizana y Beaumont, quien en ese momento ocupaba la silla arzobispal de México, tomó cartas en el asunto. Tampoco hemos podido averiguar si Valero se ordenó por insistencia de su padre.

Las actividades que los residentes del seminario realizaron diariamente - oración, examen de conciencia, lección espiritual, mortificación, práctica de las virtudes y clases - tuvieron como finalidad formar curas capaces de preparar y pronunciar sermones convincentes, celebrar la misa, impartir los sacramentos correctamente y leer con fervor el oficio divino. También tuvieron como objetivo convertir a los ministros en hombres virtuosos, dóciles, humildes, afables, disciplinados y decentes. Su último propósito fue el de transformarlos en individuos de literatura y excelente formación. Todas estas cualidades irían acompañadas

\footnotetext{
${ }^{61}$ AGNM, Indiferente virreinal, caja 3861, exp. 016, fs. 2r-7v.
} 
de algo mucho más trascendental, una vocación auténtica que sería examinada en los ejercicios espirituales.

\section{A MANERA DE CONCLUSIÓN}

Con la fundación del seminario de instrucción, retiro voluntario y corrección de Tepotzotlán, el arzobispo Haro y Peralta intentó hacer frente a tres problemas fundamentales que el clero secular novohispano había arrastrado desde hacía siglos: la relajación moral, la indisciplina y la formación deficiente. Los medios utilizados para tan importante empresa se sustentaron en los planteamientos reformistas vertidos en el Tomo Regio, en el Concilio de Trento, en el Tercer Concilio Provincial Mexicano, en otras juntas eclesiásticas y en los textos del concilio celebrado en la Nueva España en 1771.

Así pues, el proyecto emprendido por el arzobispo de México tuvo como finalidad formar al cura ideal que había sido concebido desde tiempo atrás. Para alcanzar este objetivo, el prelado consideró pertinente que el establecimiento recibiera tres tipos de habitantes correspondientes al mismo número de funciones que debía desempeñar: seminario de instrucción, casa de retiro voluntario y cárcel.

Con relación a la educación, el colegio se distinguió de los demás establecimientos de enseñanza de su época por impartir aquellas materias que llevaran a perfeccionar los conocimientos adquiridos en otros centros. Dichos conocimientos permitirían fijar una visión de la moral y de la disciplina católica, evitando con ello la relajación moral del clero y la laxitud de doctrinas. Asimismo, se buscaba que los clérigos leguas u ordenados a título de idioma, conocieran bien las lenguas de la región para predicar y confesar de forma correcta a los indígenas. Por último, se intentó reafirmar mediante reglas y criterios lo aprendido sobre las doctrinas de los padres de la Iglesia, las fuentes de la misma, el mensaje revelado y los concilios.

Para que los residentes detentaran las virtudes propias de un buen eclesiástico y se beneficiaran espiritualmente, Núñez de Haro estableció una serie de actividades cotidianas que ya hemos señalado, además de una serie de reglas disciplinares para regular la conducta individual y colectiva del clero.

Finalmente, el redactor de las constituciones se preocupó de que los clérigos del arzobispado ejercieran su ministerio de forma adecuada, para lograr este objetivo, los habitantes del seminario debían acudir a conferencias de moral, liturgia, ritos y ceremonias, aprender el arte de predicar, conocer el misal y el catecismo del Concilio y practicar la forma en que debía oficiarse la misa. 
A través de los tres aspectos indicados, el establecimiento lograría formar y transformar a sus residentes en ministros con una instrucción, vocación, actitud y virtudes tan apreciadas como la probidad, la obediencia, la sencillez, la gentilidad, el respeto hacia ellos mismos y hacia los demás.

La trascendencia que tuvo este seminario sólo pude medirse, por ahora, a la luz de sus constituciones, pues la otra información con que contamos hasta el momento es sumamente escasa. No obstante, debemos apuntar que en 1784, el regente de la Real Audiencia de México, en una misiva enviada a Carlos IV, expresaba que los seminaristas del colegio se distinguían del resto del clero americano, por sus buenas cualidades y su excelente formación. ${ }^{62}$ Esta afirmación ya no se sostiene en 1816, pues en la visita efectuada en ese año, se muestra una institución debilitada por los problemas económicos y, principalmente, por la ausencia de ordenados.

El seminario que hemos revisado resultó novedoso o único en su tipo al incluir entre sus habitantes a eclesiásticos desengañados, enfermos o ancianos y a clérigos díscolos y criminosos, junto con los ordenados. Ambas funciones como bien señala Luisa Zahino, no habían sido contempladas hasta entonces como necesarias y primordiales para mejorar la condición moral del clero. ${ }^{63}$ Finalmente debemos señalar que en las constituciones del colegio nunca se intentó castigar a los infractores sino rehabilitarlos personal y profesionalmente.

En futuras investigaciones será necesario acercarnos a otras fuentes para conocer más sobre la historia del seminario y sobre su funcionamiento cotidiano. También convendrá estudiar su relación con otras entidades y funcionarios encargados de la ordenación y de la sanción de los clérigos delincuentes.

\section{BiBLIOGRAFÍA}

Alejos Grau C. J. 2008. «Vida cotidiana del clero novohispano en el apogeo de la ilustración colonial» Uku Pacha. Revista de Investigaciones Históricas 12: 71-86.

Alonso, J. C. 2000. «Adaptaciones a la retórica eclesiástica: fray Luis de Granada y fray Diego Valadés», en J. Arribas (coord.), Temas de retórica hispana renacentista. México: Instituto de Investigaciones Filológicas.

Cervantes Bello, F. J. y Cano Moreno, S. M. 2005. «El IV Concilio Provincial Mexicano», en M. P. Martínez López-Cano y F. J. Cervantes Bello (coords.), Los concilios provinciales en Nueva España. Reflexiones e influencias. México: Instituto de Investigaciones Históricas/Benemérita Universidad Autónoma de Puebla.

\footnotetext{
${ }^{6}$ Ídem.

${ }^{63}$ Zahino Peñafort, L. 1996: 88.
} 
González M., J. R. y Ordoñez A., M. M. (comps.), 1993. Colegio seminario de Tepotzotlán para instrucción, retiro voluntario y corrección de clérigos seculares. Constituciones formadas por el arzobispo de México (El ilustrísimo señor doctor don Alonso Núñez de Haro y Peralta) para su gobierno, y cédula del 28 de marzo de 1777 aprobándolas con las limitaciones y declaraciones que expresa. México: Instituto de Antropología e Historia.

Gutiérrez Lorenzo, M.P. 2005. «Universitarios alcalaínos en la Nueva España. Destinos profesionales en la Nueva Galicia» en E. González González y M. L. Pérez Puente (coords.), Permanencia y cambio I. Universidades hispánicas, 1551-2001. México: Centro de Estudios sobre la Universidad/Facultad de Derecho.

1805. Novísima recopilación de la leyes de España dividida en XII libros en que se reforma la recopilación publicada por el señor Felipe II en el año de 1567 reimpresa últimamente en el de 1775. Y se incorporar las pragmáticas, cédulas, decretos, órdenes y resoluciones reales, y otras providencias no recopiladas y expedidas hasta el de 1804. Madrid.

Ripoll López, G. 1989. «Historiografía y numismática visigodas entre los siglos XVI y XVIII: Ambrosio Morales y Enrique Florez». Archéologie aujourd 'hui 2: 58-64.

Rodríguez Ogarrio, J. C. 2005. La política educativa de los jesuitas hacia los indígenas entre 1575 y 1594. México: Facultad de Filosofía y Letras.

Romero Delgado, J. 1986, Ideas pedagógicas de Nuñez de Haro, a través de las constituciones que redactó para el seminario de Tepotzotlán: Nueva España 1777. Huelva: Copistería Escuela Universitaria.

Romero Delgado, J. 1990. «El obispo Ruiz de Cabañas y la erección y fundación del Colegio Clerical Del Divino Salvador: Guadalajara, 1802». Communio 2: 1-10.

Romero Delgado, J. 1991. Aportaciones pedagógicas desde la formación del clero. Los seminarios reformados por Luis de Cabañas 1800-1813) Cuestiones pedagógicas 1. Huelva.

1807. Sermones escogidos, pláticas espirituales privadas y dos pastorales anteriormente impresas en México del excelentísimo señor D. Alonso Núñez de Haro y Peralta, virrey interino, gobernador y capitán general que fue de Nueva España; caballero prelado, gran cruz de la orden española de Carlos III, del Consejo de S.M., arzobispo de México, etc. Con el retrato del autor y un resumen histórico de su vida. Tomo III, cartas pastorales I y II. Madrid: Imprenta de la hija de Ibarra.

Sierra Nava-Lasa, L. 1975. El cardenal Lorenzana y la ilustración. Madrid: Fundación Universitaria Española.

Vergara Ciordia, J. 2005. «El seminario conciliar en la América hispana (15631800)», en J. I. Saranyana (dir.) y C. J. Alejos Grau (coord.), Teología en la América Latina, Volumen II/1. Escolástica barroca, ilustración y preparación de la Independencia (1665-1810). Madrid: Iberoamericana/Vervuert.

Vergara Ciordia, J. 2004, Historia y pedagogía del seminario conciliar en Hispanoamérica, 1563-1800. Madrid: Dykinson.

Hispania Sacra, LXVI

134, julio-diciembre 2014, 601-619, ISSN: 0018-215X, doi: 10.3989/hs.2014.063 
Zahino Peñafort, L. (recop.), 2009. El cardenal Lorenzana y el IV Concilio Provincial Mexicano. México: Instituto de Investigaciones Jurídicas.

Zahino Peñafort, L. 1996. Iglesia y sociedad en México, 1765-1800. Tradición, reforma y reacciones. México: Instituto de Investigaciones Jurídicas. 